\title{
Accumulation capacity of cadmium and copper and their effects on photosynthetic performance in Azolla filiculoides Lam. under induced rhizofiltration
}

\section{Capacidad de acumulación de cadmio y cobre, y sus efectos en el desempeño fotosintético en Azolla filiculoides Lam. bajo rizofiltración aumentada}

\author{
Aly Valderrama ${ }^{1,4 *}$, Danny E. Carvajal ${ }^{2}$, Patricio Peñallillo $^{3} \&$ Jaime Tapia ${ }^{4}$ \\ 'Universidad Bernardo O’Higgins, Centro de Investigación en Recursos Naturales y Sustentabilidad, General Gana 1702, \\ Santiago, Chile. \\ 2Departamento de Biología, Facultad de Ciencias, Universidad de La Serena, Casilla 554, La Serena, Chile; Instituto de \\ Ecología y Biodiversidad (IEB); Programa de Doctorado en Biología y Ecología Aplicada, Universidad de La Serena, La \\ Serena, Chile. \\ ${ }^{3}$ Instituto de Ciencias Biológicas, Universidad de Talca, Casilla 747, Talca, Chile. \\ ${ }^{4}$ Laboratorio de Química Ambiental, Instituto de Química de Recursos Naturales, Universidad de Talca, Casilla 747, Talca, \\ Chile. \\ *aly.valderrama@ubo.cl
}

\begin{abstract}
This study evaluated the capacity of Azolla filiculoides to enhance heavy metal accumulation through the addition of different concentrations of cadmium $(\mathrm{Cd})$ and copper $(\mathrm{Cu})$, as ethylenediaminetetraacetic acid (EDTA) complexes, under hydroponic conditions. The physiological effect was determined by Photosynthetic efficiency (Fv/Fm) as an indicator of plant stress, and heavy metal content was measured with flame atomic absorption spectroscopy in the whole plants. The results obtained in rhizofiltration systems did not show an increase in accumulation when Cd-EDTA was added, but the $\mathrm{Cu}$-EDTA increased the accumulation of $\mathrm{Cu}$ by plants. Although the Fv/Fm was decreased in all treatments, only the Cd-EDTA complex caused damage to photosystem II (PSII) activity, and that damage was critical. These results coincide with the higher toxicity of cadmium to plants; the quantity of cadmium in the plants, although small, was indeed harmful to them. The correlation analysis for both heavy metals coincides with the assumption that the heavy metals on leaf tissue affected the photosynthetic metabolism. This research makes a new contribution to the field by evaluating EDTA-induced Azolla rhizofiltration in aquatic systems, a departure from the majority of the literature on the topic, which examines EDTA in soil remediation. In future, further study is needed on the interactions of EDTA with other ions and the physiological consequences for different plant species.
\end{abstract}

KeYwords: EDTA, Azollaceae, cadmium, copper, photosynthetic metabolism.

\section{RESUMEN}

El presente estudio evaluó la capacidad de Azolla filiculoides de incrementar la acumulación de metales pesados a través de la adición de diferentes concentraciones de cadmio $(\mathrm{Cd})$ y cobre $(\mathrm{Cu})$, como complejos del ácido etilendiaminotetraacético (EDTA), bajo condiciones hidropónicas. Los efectos fisiológicos de la capacidad fotosintética fueron determinados por la eficiencia fotosintética ( $\mathrm{Fv} / \mathrm{Fm})$ como un indicador de estrés en las plantas, y el contenido de metales pesados en la planta completa, fue medido mediante espectroscopia de absorción atómica. Los resultados obtenidos en los sistemas de rizofiltración no lograron alcanzar un incremento en la acumulación de Cd ante la adición de Cd-EDTA, pero el Cu-EDTA aumentó la acumulación de cobre. Aunque el Fv/Fm fue menor en todos los tratamientos, sólo el complejo Cd-EDTA causó daño en la actividad del PSII, y este resultó crítico. Estos resultados coinciden con la alta toxicidad del cadmio en las plantas, la cantidad de cadmio en las plantas, aunque pequeña, resultó dañina. El análisis de correlación para ambos metales pesados concuerda con el supuesto que los metales pesados en el tejido foliar afectan el metabolismo fotosintético. Esta investigación hace una nueva contribución al área, por cuanto se evalúo la rizofiltración inducida con EDTA utilizando Azolla en sistemas acuáticos, cuando la mayoría de la literatura evalúa la remediación en suelos con EDTA. En el futuro, se necesitan más investigaciones enfocada en la interacción del EDTA con otros iones y las consecuencias fisiológicas en diferentes especies de plantas.

Palabras clave: EDTA, Azollaceae, cadmio, cobre, metabolismo fotosintético. 


\section{INTRODUCTION}

Throughout history, human settlement has led to the emergence of hotspots of different forms of pollution involving organic and inorganic compounds. Among the inorganic compounds, heavy metals may come from alkaline batteries, electronic equipment, fossil fuel incineration, gases released from industrial activities and mining waste solids (Raskin et al. 1994). In addition, low concentrations of heavy metals in domestic wastewater can cause highly toxic symptoms in humans and ecosystems, and their accumulation over time can eventually affect quality of life (Cheng et al. 2005, Singh et al. 2004). Heavy metals are present in both soils and streams as natural components (Raskin et al. 1994), and although plants have the capacity to degrade or sequester many toxic compounds, they are also sensitive to many of them (Davis et al. 2002). Plants' stress response to the presence of pollutants, including metals, can alter their capacity to control the uptake of such pollutants, and indeed in some cases may lead them to increase their uptake, which may seriously threaten plant viability (Almeida et al. 2009, Stepniewska et al. 2005). However, these effects depend on the pollutant, plant species, concentration and time of exposure to the pollutant (Davis et al. 2002). For example, copper $(\mathrm{Cu})$ is an essential micronutrient and necessary for all organisms (Weser et al. 1979), but becomes toxic at elevated levels (Flemming \& Trevors 1989). In plants, copper-induced iron deficiency is considered a typical copper toxicity symptom (Marchner 1995). In addition, at toxic levels $\mathrm{Cu}$ affects photosystem II (PSII) by modifying the electron chain during photosynthesis at the plastocyanin and superoxide dismutase levels, causing a decrease in the photosynthetic rate and in effective photosynthesis (Epstein \& Bloom 2005). On the other hand, cadmium (Cd) is considered the pollutant most toxic to organisms, and its release into the environment is associated with human activities (Das et al. 1997; Nriagu \& Pacyna 1988; Sanità di Toppi \& Gabbrielli 1999). Once Cd is inside the plant cell, it causes chlorosis by inhibiting FeIII-reductase and generating ion deficiency, which affects photosynthesis (Alcantara et al. 1994). It also has a harmful effect on the photosynthetic apparatus, mainly in the harvest electron complex II and in PSI and PSII (Krupa 1988, Siedlecka \& Baszynsky 1993, Siedlecka \& Krupa 1996).

Phytoremediation, a new biotechnology intended to reduce heavy metal concentrations, has emerged as a useful tool for the remediation of water, soil and air (Raskin et al. 1997). It works with the plant's metabolic activity, which accumulates heavy metals on the tissue (McGrath et al. 2002). The phytoremediation of polluted water, or rhizofiltration, is a relatively new technology (Dushenkov et al. 1997). The process, also referred to as phytofiltration, is based on a hydroponically grown plant medium that has been shown to be efficient in removing heavy metals from water (Raskin et al. 1997). However, some of these elements play no known physiological role (Lasat 2002, McGrath \& Zhao 2003), and only $0.2 \%$ of the total angiosperms have been reported to have phytoremediation potential; but the use of chelated compounds could increase the number of species useful for this process (McGrath \& Zhao 2003). Classic phytoremediation is defined as the circumstance in which the pollutants were present as ions in the solution or environment, whereas enhanced phytoremediation establishes that chemical modifications of the rhizosphere through the addition of chelated compounds can improve the plant accumulation of ions (Evangelou et al. 2007).

Ethylenediaminetetraacetic acid (EDTA) is the chelate most often used for enhanced phytoremediation of soils, but its properties and interactions in the aquatic environment have been little studied (Bonfranceschi et al. 2009, Chen et al. 2010, January et al. 2008, Li et al. 2009). In soil, it is known that EDTA can change metal speciation and thereby affect the metal's bioavailability in the soil, but this has not been studied in aquatic systems. EDTA's ability to increase metal concentration in the soil solution depends on multiple factors, including metal and EDTA concentration, the presence of competitor ions, metallic species, distribution in the soil fraction, soil $\mathrm{pH}$, adsorption of free ions or complexes by the soil particle and the constant of complex formation (McGrath et al. 2002, Saifullah et al. 2009). EDTA is suggested as one of most effective chelating agents in assisting phytoextraction, which can increase metal mobility in the soil solid phase, thus enhancing the concentrations of heavy metals in plant shoot tissue (Hong et al. 1999, Meers et al. 2005, Wong et al. 2004). The assumed reason for this is that P-Type ATPases are responsible for the translocation of both necessary (e.g. $\mathrm{Cu}^{2+}, \mathrm{Zn}^{2+}, \mathrm{Mn}^{2+}$ ) and nonessential metals (e.g. $\mathrm{Cd}^{2+}, \mathrm{Pb}^{2+}, \mathrm{Hg}^{2+}$ ) through the biological membranes (Ghestem \& Bermond 1998, Rensing et al. 1998, Williams et al. 2000). EDTA may induce the activation of ATPases in the plasma membrane, producing changes on ion transport through the membrane. Additionally, EDTA regulates a protein membrane that is related to $\mathrm{Pb}$ transport function, and thus $\mathrm{Pb}$ can easily be translocated from roots to aerial parts of the plant through the prevention of cell wall retention (Ghestem \& Bermond 1998). In general, the chelant-enhanced uptake of $\mathrm{Cu}$ in plant shoots has been found to be minimal (Kayser et al. 2000, Kulli et al. 1999, Lombi et al. 2001, Römkens et al. 2002, Shen et al. 2002, Thayalakumaran et al. 2003, Wenzel et al. 2003), while EDTA application reportedly reduced $\mathrm{Cd}$ concentrations in some plant species (Luo et al. 2006).

The increased accumulation of heavy metals in plants is a multifactorial phenomenon, with physiological response depending upon the kinds of heavy metals, chemical specificity, the $\mathrm{pH}$ of the growth medium and other factors. 
The Photosynthetic efficiency $(\mathrm{Fv} / \mathrm{Fm})$ is often used as a stress indicator, and describes the potential yield of the photochemical reaction (Björkman \& Demmig 1987) due to the location of the heavy metals in the Photosystem II (PSII) and Photosystem I (PSI); the Fv/Fm decreased in plants when they were exposed to a toxic level of the heavy metals. Sánchez-Viveros et al. (2010) evaluated the effects of exposure to $\mathrm{Cu}^{2+}$ in Azolla caroliniana Willd. and $A$. filiculoides $\mathrm{Lam}$. in the $\mathrm{Fv} / \mathrm{Fm}$, where the $\mathrm{Cu}^{2+}$ presence has a negative effect on the Fv/Fm; a similar effect was found in other plants (Küpper et al. 2002, Sivaci et al. 2008). The reduction of the $\mathrm{Fv} / \mathrm{Fm}$ may be explained by the $\mathrm{Cu}^{2+}$ (and other divalent ions) affecting the photochemical reactions in the PSII, where the electron transport is blocked (Tyystjärvi 2008).

The plant genus most studied for heavy metal accumulation is Azolla, which has been investigated for use in the remediation of different kinds of pollutants, including organic and inorganic compounds, and in different growth media (Arora et al. 2004, Dai et al. 2006, Rai 2008, Sela et al. 1989, Sela et al. 1988, Stepniewska et al. 2005). Azolla filiculoides is a small aquatic fern that has a symbiotic relationship with the heterocystous blue-green alga, Anabaena azollae Strasburger (Lumpkin \& Plucknett 1980). In regard to its distribution, it is a cosmopolitan species growing in freshwater streams with low levels of mineral nutrients, and its ability to fix nitrogen from the atmosphere allows it to grow under a variety of conditions (Sood et al. 2011). Azolla's ability to accumulate heavy metals has been studied with different elements (e.g. Ag, Cd, Cu(II), Cr III, $\mathrm{Cr}(\mathrm{IV}), \mathrm{Cr}(\mathrm{VI}), \mathrm{Hg}, \mathrm{Ni}$ (II), $\mathrm{Pb}, \mathrm{Zn}$ ) on live and immobilized Azolla tissues (Arora et al. 2004, Bennicelli et al. 2004, Elmachliy et al. 2011, Fogarty et al. 1999, Khosravi et al. 2005, Mashkani \& Ghazvini 2009, Stepniewska et al. 2005, Valderrama et al. 2013, Zhao \& Duncan 1997). The response of A. filiculoides to EDTA complex exposure has not been studied previously, and research on this topic has provided knowledge of the species's heavy metal accumulation capability and the physiological consequences of it. As both heavy metals, $\mathrm{Cu}$ and $\mathrm{Cd}$, are toxic and harmful to humans and plants, this investigation sought to evaluate the induced $\mathrm{Cd}$ and $\mathrm{Cu}$ rhizofiltration of Azolla filiculoides.

The aims of this study were: i) to assess the capacity of A. filiculoides $\mathrm{Lam}$. to accumulate $\mathrm{Cd}$ and $\mathrm{Cu}$, in the form of EDTA complexes, in an induced rhizofiltration system (Hernández-Allica et al. 2007, Kari \& Giger 1996); ii) to determine the stress effect in an induced rhizofiltration system through the stress indicator of PSII photochemistry $(\mathrm{Fv} / \mathrm{Fm})$; and iii) to correlate the accumulation of heavy metals $(\mathrm{Cd}$ and $\mathrm{Cu})$ by $A$. filiculoides with the $\mathrm{Fv} / \mathrm{Fm}$ as physiological responses, because the exact tolerance and physiological mechanisms of $\mathrm{Cd}$ and $\mathrm{Cu}$ toxicity as EDTA complex have been scarcely studied in an induced phytoremediation with A. filiculoides.

\section{MATERIALS AND METHODS}

Plant MATERIAL

Plant material was obtained from the Lircay River (35²3'34'S, 71³6'49.4'W) in Chile's Maule Region. The plants were identified and the voucher was deposited in the herbarium of the Universidad de Concepción (CONC 171639).

EXPERIMENTAL CONDITIONS

The rhizofiltration system was based on the International Rice Research Institute (IRRI) nutrient solution, as proposed by Watanabe et al. (1992). Experimental conditions were controlled in a laboratory, with a temperature range of 20$25^{\circ} \mathrm{C}$, a mixed light source (fluorescent tubes and tungsten bulb), light intensity of $135 \mu \mathrm{mol} \mathrm{m} \mathrm{m}^{-1}$ at the level of the plants, a $16 \mathrm{~h}: 8 \mathrm{~h}$ photoperiod (light:dark) on an automatic timer and continuous aeration at the bottom of the containers using an aquarium pump (Elite 800, $1200 \mathrm{~mL} \mathrm{~min}^{-1}$ and 2.5 psi); on each treatment $50 \mathrm{~g}$ fresh weight collected in the Lircay River was used, having previously been acclimatized by 10 days in the experimental conditions.

The enhanced rhizofiltration treatments were formulated by adding a Cd-EDTA or Cu-EDTA complex, which was prepared by adding a $6.2 \mathrm{mM}$ EDTA solution to a $1 \mathrm{~N} \mathrm{KOH}$ solution. The final $\mathrm{Cd}$-EDTA and $\mathrm{Cu}$-EDTA solutions were $0.12 \mathrm{mM}$ and $0.082 \mathrm{mM}$, respectively. Cd-EDTA and $\mathrm{Cu}-$ EDTA were evaluated at concentrations of $0.03,0.30,0.70$, $1.35,2.00$, and $2.70 \mathrm{mg} \mathrm{L}^{-1}$, and 0.10, 0.25, 0.50, 0.80, 1.00, 1.60 and $2.60 \mathrm{mg} \mathrm{L}^{-1}$, respectively (Table I). The control treatments were established without the addition of $\mathrm{Cd}$ EDTA or $\mathrm{Cu}$-EDTA. In all cases, six replicates per treatment were evaluated, including the control systems, with seven days of exposure.

\section{PhotosynthetiC EFFICIENCY}

As an indicator of physiological performance, the maximum quantum yield of PSII (Fv/Fm) was determined in fully expanded leaves of $A$. filiculoides in three randomly selected plants from each container of rhizofiltration treatments, and was measured using an open gas-exchange system with an integrated fluorescence chamber (Li-6400; Li-Cor, Inc., Lincoln, NE). The Fv/Fm was estimated as the ratio of the variable $(\mathrm{Fv})$ to maximum fluorescence $(\mathrm{Fm})$ of darkadapted leaves as $(\mathrm{Fv} / \mathrm{Fm}=[\mathrm{Fm}-\mathrm{Fo}] / \mathrm{Fm})$, where Fo is the minimum or initial fluorescence to about $0.5 \mu \mathrm{mol}$ photon $\mathrm{m}^{-2} \mathrm{~s}^{-1}$ of light, and Fm is the maximum fluorescence after the application of a saturating flash of about 10,000 $\mu \mathrm{mol}$ photon $\mathrm{m}^{-2} \mathrm{~s}^{-1}$ and $0.8 \mathrm{~s}$ duration (Maxwell \& Johnson 2000).

Metal DETERMinAtion IN PLANT TISSUES

Whole plants were harvested and rinsed with deionized water and then dried in an oven at $106^{\circ} \mathrm{C}$ until a constant 
weight was achieved ( $\sim 500 \mathrm{mg}$ dry weight). These were then ground up in a porcelain mortar. The $\mathrm{Cd}$ determination was made by wet digestion and the $\mathrm{Cu}$ determination was made by calcination digestion (Allen et al. 1986). Heavy metal content was measured in a flame atomic absorption spectrophotometer (Unicam Solaar mod. 969). To evaluate experimental reproducibility, sampling analyses were repeated six times and chemical analysis was run in triplicate. Each data set was calculated at a $95 \%$ confidence level $(p<0.05)$ to determine margins of error (Long \& Winefordner 1983). A correlation coefficient for a calibration curve of 0.9994 or greater was obtained for both copper and cadmium. In addition, the cadmium measurement included a deuterium background corrector. The limits of detection for cadmium and copper were 0.083 and $0.094 \mathrm{mg} \mathrm{L}^{-1}$, respectively. The quantitation limit for the analyses and the measured conditions of $\mathrm{Cd}$ and $\mathrm{Cu}$ were 11.100 and $23.317 \mu \mathrm{g} \mathrm{kg}^{-1}$, respectively. Certified standard reference materials for both metals were used for calibration and quality assurance on each analytical batch (SRM-1570, spinach, National Institute of Standards and Technology). Blank reagents and analytical duplicates were also used with each chemical treatment to ensure accuracy and precision in the analysis. The recovery rates of the reference materials for cadmium and copper were $103 \%$ and $89.7 \%$, respectively.

StATISTICAL ANALYSIS

The data were analysed using one-way analysis of variance (ANOVA), in which the statistical significance of the treatments was $95 \%$, with the least statistical difference (LSD) equal to a $p$ value of $<0.05$, and the Multiple Range test was used to compare the means. All data analyses were performed with Statgraphics Centurion XV software, and the correlation analysis was carried out using JMP 8 software; statistical significance was determined when $\mathrm{p}$ was $<0.05$. The bivariate correlation was made by fit equation with better $\mathrm{r}^{2}$ value, where the values between 0.25 and 0.50 have a low to moderate correlation; between 0.50 and 0.75 have a moderate to significant correlation; and between 0.75 and 1.00 have a very significant correlation (Salkind 1999).

\section{RESULTS}

\section{Cadmium aCcumulation}

The Cd levels in the control plants indicated unpolluted conditions in the source (Lircay River) and in the rhizofiltration system (Table I). The accumulation capability of A. filiculoides under EDTA rhizofiltration conditions was lower than under classic rhizofiltration conditions (Valderrama et al. 2013). When A. filiculoides was exposed at equal $\mathrm{Cd}$ concentrations in the grown medium with 1.0 and $2.5 \mathrm{mg} \mathrm{L}^{-1}$ of $\mathrm{Cd}$, the $\mathrm{Cd}$ accumulation was 188.70 and $673.53 \mathrm{mg} \mathrm{kg}^{-1}$, respectively. In this investigation at the maximum concentrations, $2.70 \mathrm{mg} \mathrm{L}^{-1}$ of Cd-EDTA in the growth media, the highest accumulation achieved was $93.11 \pm 10.07 \mathrm{mg} \mathrm{kg}^{-1}$, suggesting some effects of EDTA in the accumulation capability. These results were confirmed by the ANOVA analysis yielding a $p$ value less than 0.05 , which implies a statistically significant difference between the treatments and confirms the adequacy of the experimental design.

\section{COPPER ACCUMUlation}

Exposure of Azolla filiculoides to Cu-EDTA has not been previously reported or widely studied, and water-enhanced rhizofiltration was developed only recently with other species (Sun et al. 2009; Zhao et al. 2010). The highest copper accumulation was achieved at $2.60 \mathrm{mg} \mathrm{L}^{-1}$ in the growth medium and accumulate $1169.45 \pm 204.93 \mathrm{mg} \mathrm{kg}^{-1}$, which are better than the classic rhizofiltration (Valderrama et al. 2013). The ANOVA analyses showed a statistical significance, as $\mathrm{p}$ values between treatments were less than 0.05 .

\section{PhysiologicAl RESPONSE}

The concentrations of $\mathrm{Cd}$ and $\mathrm{Cu}$ achieved in the EDTA phytoremediation treatments indicated a decrease in the $\mathrm{Fv} /$ Fm (Table I). These results suggest that heavy metals have a highly toxic effect on photosynthetic performance.

\section{Correlation analysis}

The correlation analysis confirmed the toxicity and physiological effect of cadmium and copper (Fig. 1). The relationship between cadmium and copper accumulation with $\mathrm{Fv} / \mathrm{Fm}$, respectively, is explained by a polynomial quadratic equation, where $\left(r^{2}=0.484, p\right.$ value $\left.=0.0062\right)$ and $\left(\mathrm{r}^{2}=0.417, \mathrm{p}\right.$ value $\left.=0.0027\right)$, respectively. The graph explains the influence on the photosynthetic apparatus and confirms the harmfulness of cadmium and copper for the plants.

In addition, the polynomial quadratic equation explained three phases of response by the plants; the graph explains the influence on the photosynthetic apparatus and confirms the harmfulness of cadmium and copper for the plants. There were three phases of response by the plants. First, non-harmful concentrations of cadmium or copper were observed, and the $\mathrm{Fv} / \mathrm{Fm}$ were not affected by the presence of heavy metals in this tissue. However, when the concentrations of metal-EDTA are higher, the concentrations in the tissue were harmful and the $\mathrm{Fv} / \mathrm{Fm}$ observed were less; at these points, the heavy metals interfered with the PSII and PSI. Finally, the plants' response was to start an exclusion process of heavy metals; the concentrations inside the plants were now at their highest and did not allow the entrance of more cadmium or copper ions. Because of the exclusion process, the $\mathrm{Fv} / \mathrm{Fm}$ were slightly higher in the third phase than in the second. 

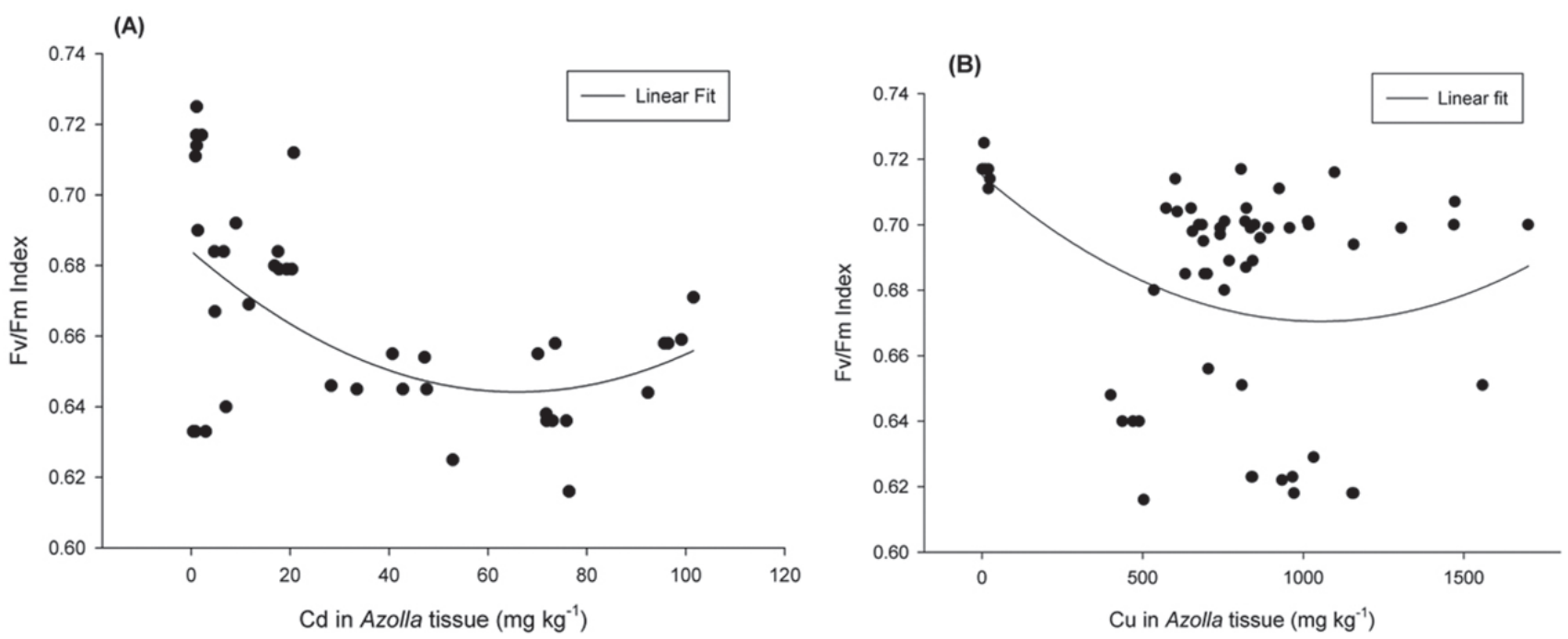

FIGURE 1. Correlation analysis between the cadmium and copper accumulation capability of Azolla filiculoides in induced rhizofiltration systems associated with the physiological responses, as Fv/Fm. (A) Relationship between Cd accumulation (mg kg-1) and Fv/Fm; (B) Relationship between $\mathrm{Cu}$ accumulation $\left(\mathrm{mg} \mathrm{kg}^{-1}\right)$ and $\mathrm{Fv} / \mathrm{Fm}$.

FIgURA 1. Análisis de correlación entre la capacidad de acumulación de cadmio y cobre de Azolla filiculoides en sistema de rizofiltración inducido asociado a la respuesta fisiológica, como Fv/Fm. (A) Relación entre acumulación de Cd ( $\left.\mathrm{mg} \mathrm{kg}^{-1}\right)$ y Fv/Fm; (B) Relación entre acumulación de $\mathrm{Cu}\left(\mathrm{mg} \mathrm{kg}^{-1}\right)$ y Fv/Fm.

TABLE I. Induced-EDTA rhizofiltration of cadmium and copper by Azolla filiculoides in hydroponic systems.

TABLA I. Rizofiltración EDTA-inducida de cadmio y cobre en sistemas hidropónicos de Azolla filiculoides.

\begin{tabular}{|c|c|c|c|c|c|}
\hline $\mathrm{Cd}\left(\mathrm{mg} \mathrm{L}^{-1}\right)$ & $\begin{array}{c}\text { Cd in Azolla } \\
\text { (d.w.) }\left(\mathrm{mg} \mathrm{kg}^{-1}\right) \pm \mathrm{SD} \dagger\end{array}$ & $\mathrm{Fv} / \mathrm{Fm} \pm \mathrm{SD} \dagger$ & $\mathrm{Cu}\left(\mathrm{mg} \mathrm{L}^{-1}\right)$ & $\begin{array}{c}\mathrm{Cu} \text { in Azolla } \\
\text { (d.w.) }\left(\mathrm{mg} \mathrm{kg}^{-1}\right) \pm \mathrm{SD} \dagger\end{array}$ & $\mathrm{Fv} / \mathrm{Fm} \pm \mathrm{SD} \dagger$ \\
\hline Control & $1.22 \pm 0.49^{\mathrm{a}}$ & $0.803 \pm 0.017^{\mathrm{a}}$ & Control & $8.97 \pm 8.86^{\mathrm{a}}$ & $0.803 \pm 0.014^{\mathrm{a}}$ \\
\hline 0.03 & $3.35 \pm 2.50^{b}$ & $0.633 \pm 0.038^{\mathrm{b}}$ & 0.10 & $500.59 \pm 106.34$ & $0.640 \pm 0.021$ \\
\hline 0.30 & $8.44 \pm 5.69 \mathrm{~b}$ & $0.684 \pm 0.013 \mathrm{~cd}$ & 0.25 & $864.04 \pm 84.71^{c}$ & $0.699 \pm 0.011^{\mathrm{c}}$ \\
\hline 0.70 & $20.53 \pm 4.06^{c}$ & $0.679 \pm 0.033^{\mathrm{cd}}$ & 0.50 & $762.69 \pm 73.44 \mathrm{bc}$ & $0.700 \pm 0.015^{\mathrm{c}}$ \\
\hline 1.35 & $44.09 \pm 6.73^{\mathrm{d}}$ & $0.645 \pm 0.017 \mathrm{bc}$ & 0.80 & $903.05 \pm 128.64^{\mathrm{c}}$ & $0.701 \pm 0.014^{\mathrm{c}}$ \\
\hline 2.00 & $73.17 \pm 2.48^{\mathrm{e}}$ & $0.636 \pm 0.020^{\mathrm{b}}$ & 1.00 & $867.16 \pm 66.29^{c}$ & $0.623 \pm 0.027$ \\
\hline \multirow[t]{2}{*}{2.70} & $93.11 \pm 10.07^{\mathrm{f}}$ & $0.658 \pm 0.014 \mathrm{bc}$ & 1.60 & $1353.22 \pm 245.58 \mathrm{e}$ & $0.700 \pm 0.007$ \\
\hline & & & 2.60 & $1169.45 \pm 204.93^{c}$ & $0.618 \pm 0.040^{b}$ \\
\hline$P(A N O V A)$ & $<0.05$ & $<0.05$ & & $<0.05$ & $<0.05$ \\
\hline
\end{tabular}

d.w. dry weight, †statistical significance was calculated by the Multiple Range test; different letters indicate significant differences between the treatment $\mathrm{p}<0.05$. / d.w. peso seco, $\uparrow$ Significancia estadística fue calculada con la Prueba de Ranqueo Múltiple; letras diferentes indican diferencias significativas entre los tratamientos con valor $\mathrm{p}<0,05$. 


\section{DISCUSSION}

January et al. (2008) showed that the capability of EDTA to accumulate chelated heavy metals depends on the heavy metals and the species studied, and the presence of EDTA alters metal speciation and metal phytotoxicity (Chen et al. 2010). Although A. filiculoides is reportedly a species with phytoremediator potential, when exposed to Cd-EDTA complex, the accumulation of the ions was not increased. If the present results are compared with Cd-classic rhizofiltration with Azolla species, the natural accumulation potential of the genus is seen to be indisputable; however, none of the historical results is lower than the Cd-EDTA complex obtained in this investigation (Arora et al. 2004, Sela et al. 1989, Stepniewska et al. 2005). Sela et al. (1989) exposed A. filiculoides to $10 \mathrm{mg} \mathrm{L}^{-1}$ of $\mathrm{Cd}$ in the medium and found that the cadmium content was highest in the dark grains located in the xylem cells and in the lower part of the stem. This phenomenon could explain the plant's lack of a favourable response to enhanced rhizofiltration of cadmium, because the EDTA complex modifies the toxicity effects of the cadmium in the plant cell, owing to a higher metabolic cost to metabolize than that produced by pure cadmium ions (Nörtemann 1999).

In the case of copper, the response obtained in $A$. filiculoides coincides with the assumption that exposure to the metal-EDTA complex increases the accumulation of the metal in plants (Evangelou et al. 2007). In the present research, when exposed to $\mathrm{Cu}$-EDTA complex in rhizofiltration treatment, A. filiculoides accumulated more $\mathrm{Cu}$ than in classic rhizofiltration (Valderrama et al. 2013). When A. filiculoides was exposed to $0.10 \mathrm{mg} \mathrm{L}^{-1}$ of $\mathrm{Cu}-$ EDTA, it accumulated $500.59 \pm 106.34 \mathrm{~kg} \mathrm{~kg}^{-1}$, similar to when it was exposed to $1.0 \mathrm{mg} \mathrm{L}^{-1}$ of $\mathrm{Cu}$ in the medium (Table I).

However, the use of EDTA could present risks to the plant, including a reduction in growth or in biomass production, necrosis, and/or chlorosis (Epstein \& Bloom 2005, Huang et al. 1997, Jiang et al. 2003, Luo et al. 2005). Azolla filiculoides displayed $\mathrm{Cu}$ selectivity in its response to $\mathrm{Cu}$-EDTA exposure, and its ability to remediate water polluted with Cu was confirmed (Fogarty et al. 1999, Sela et al. 1989). In both cases, the photosynthetic effect confirmed the foliar allocation of the ions and the EDTA-induced mobility changes caused by increased translocation from the root to the stems or leaves (Chen \& Cutright 2001, Jiang et al. 2003). Although this investigation did not evaluate the allocation of cadmium or copper in the plant tissue, it is clear that these ions allocated in the leaf tissues at the chloroplast level and affected the photosynthetic reactions by reducing $\mathrm{Fv} / \mathrm{Fm}$.

Cadmium is the element most toxic to plants (Das et al. 1997), and the Cd ions inhibited the formation of chlorophyll by interfering with photochlorophyllide reduction and the synthesis of aminoevulinic acid, resulting in the inhibition of photosynthetic $\mathrm{CO}_{2}$ fixation (Mohan \& Hosetti 1997, Weigel 1985). On the other hand, copper can cause oxidative stress by generating reactive oxygen species (ROS) such as superoxide radicals $\left(\mathrm{O}_{2}^{-}\right)$, which can be further converted to hydrogen peroxide and the hydroxyl radical $\left(\mathrm{OH}^{-}\right)(\mathrm{Cho}$ \& Seo 2005, Hall 2002). ROS affect the photosynthetic apparatus indirectly by inhibiting the repair of crucial PSII proteins (Murata et al. 2007). Although $\mathrm{Cu}$ is an essential micronutrient for plants, it can be a strong photosynthesis inhibitor at high levels, and the decrease in the Fv/Fm could be caused by peroxidation of chloroplast membranes or may result in a decrease in the electron transfer sites consequent to its binding to those sites (Frankfart et al. 2002, Maksymiec 1998, Mal et al. 2002, Sandmann \& Böger 1980, Vavilin et al. 1995).

Our results showed a marked decrease in the $\mathrm{Fv} / \mathrm{Fm}$ in cadmium treatment when compared to $\mathrm{Cu}$, and was confirmed in other aquatic macrophytes in hydroponic conditions, including Azolla pinnata R. Br., Lemna minor L., Pistia stratioides L., Spirodela polyrhiza (L.) Schleid. and Eichhornia crassipes (Mart.) Solms (Hou et al. 2007, Mishra et al. 2008, Sarkar \& Jana 1986). These results showed the toxic effects of these ions at high concentrations in the rhizofiltration systems and in the entire plants. In both analyses, the $\mathrm{r}^{2}$ was not high, but the $\mathrm{p}$ value determined that the results were statistically significant.

\section{CONCLUSION}

The novel part of this investigation was the use of the EDTA complex in the rhizofiltration system using Azolla filiculoides, which allowed the analysis of each metal (cadmium and copper) and their effects in the physiological response. Cd-EDTA rhyzofiltration was not able to increase the accumulation of $\mathrm{Cd}$ in the plant tissue beyond that obtained in classic Cd-rhyzofiltration, and even the small quantity of $\mathrm{Cd}$ in the plant was strongly harmful to photosynthetic metabolism. In comparison, Cu-EDTA rhyzofiltration increased $\mathrm{Cu}$ accumulation in the plant, while the photosynthetic response showed an effect, but not a critical one. Different concentrations of Cd-EDTA and $\mathrm{Cu}-$ EDTA in the growth medium showed a marked effect on the accumulation of the ions and altered the performance of $A$. filiculoides when the heavy metal-EDTA complexes were absorbed. The physiological plant responses were evaluated using $\mathrm{Fv} / \mathrm{Fm}$ as an indicator of stress in the photosynthetic metabolism, and the correlation furthered understanding of the complexity of plant systems. In the future, it is hoped to evaluate the plant physiological response with additional tools to build a comprehensive view of the plants' response to the medium. 


\section{ACKNOWLEDGEMENTS}

The authors thank the University of Talca for the $\mathrm{PhD}$ Fellowship extended to A.V. and for the use of its Environmental Chemistry Laboratory. We also thank the D.E.C. CONICYT doctoral fellowship (21140050).

\section{REFERENCES}

Alcantara, E., F.J. Romera, M. Cañete \& M. D. De la Guardia. 1994. Effects of heavy metals on both induction and function of root $\mathrm{Fe}(\mathrm{III})$ reductase in Fe-deficient cucumber (Cucumis sativus L.) plants. Journal of Experimental Botany 45(12): 1893-1898.

Almeida, C.M.R., A.C. Dias, A.P. Mucha, A.A. Bordalo \& M.T.S.D. VASCONCELOS. 2009. Influence of surfactants on the $\mathrm{Cu}$ phytoremediation potential of a salt marsh plant. Chemosphere 75(2): 135-140.

Allen, S.E., H.M. Grimshaw \& A.P. Rowland. 1986. Chemical analysis. In: P.D. Moore \& S.B. Chapman (eds.), Methods in Plant Ecology, pp. 285-344. Oxford, Blackwell Scientific Publication, London.

Arora, A., A. Sood \& P.K. Singh. 2004. Hyperaccumulation of cadmium and nickel by Azolla species. Indian Journal of Plant Physiology 9(3): 302-304.

Bennicelli, R., Z. Stepniewska, A. Banach, K. Szajnocha \& J. Ostrowski. 2004. The ability of Azolla caroliniana to remove heavy metals $\mathrm{Hg}(\mathrm{II}), \mathrm{Cr}(\mathrm{III}), \mathrm{Cr}(\mathrm{VI})$ from municipal waste water. Chemosphere 55(1): 141-146.

Buörkman, O. \& B. Demmig. 1987. Photon yield of $\mathrm{O}_{2}$ evolution and chlorophyll fluorescence at $77 \mathrm{k}$ among vascular plants of diverse origins. Planta 170(4): 489-504.

Bonfranceschi, B.A., C.G. Flocco \& E.R. Donati. 2009. Study of the heavy metal phytoextraction capacity of two forage species growing in a hydroponic environment. Journal of Hazardous Materials 165(1-3): 366-371.

Chen, H. \& T. Cutright. 2001. EDTA and HEDTA effects on Cd, $\mathrm{Cr}$, and Ni uptake by Helianthus annuus. Chemosphere 45(1): 21-28.

Chen, J.-C., K.-S. Wang, H. Chen, C.-Y. Lu, L.-C. Huang, H.-C. Li, T.-H. Peng \& S.-H. Chang. 2010. Phytoremediation of $\mathrm{Cr}$ (III) by Ipomonea aquatica (water spinach) from water in the presence of EDTA and chloride: Effects of Cr speciation. Bioresource Technology 101(9): 30333039.

Cheng, Y., C. WAng \& Z. Wang. 2005. Residues and source identification of persistent organic pollutants in farmland soils irrigated by effluents from biological treatment plants. Environment International 31(6): 778-783.

Cho, U.H., \& N.H. Seo. 2005. Oxidative stress in Arabidopsis thaliana exposed to cadmium is due to hydrogen peroxide accumulation. Plant Science 168(1): 113-120.

DaI, L.-P., Z.-T. Xiong, Y. Huang \& M.-J. Li. 2006. Cadmiuminduced changes in pigments, total phenolics, and phenylalanine ammonia-lyase activity in fronds of Azolla imbricata. Environmental Toxicology 21(5): 505-512.

Das, P., S. Samantaray \& G.R. Rout. 1997. Studies on cadmium toxicity in plants: A review. Environmental Pollution
98(1): 29-36.

Davis, L., S. Castro-Díaz, Q. Zhang \& L. Erickson. 2002. Benefits of vegetation for soils with organic contaminants. Critical Reviews in Plant Sciences 21(5): 457-491.

Dushenkov, S., Y. Kapulnik, M.J. Blaylock, B. Sorochinsky, I. RASKIN \& B. EnSLEY. 1997. Phytoremediation: a novel approach to an old problem. In: D. L. WisE (eds.), Global Environmental Technology, pp. 563-572. Amsterdam, The Netherlands.

Elmachliy, S., B. Chefetz, E. Tel-Or, L. Vidal, A. Canals \& A. GedanKen. 2011. Removal of silver and lead ions from water wastes using Azolla filiculoides an aquatic plant, which adsorbs and reduces the ions into the corresponding metallic nanoparticles under microwave radiation in $5 \mathrm{~min}$. Water, Air and Soil Pollution 218(1): 365-370.

Epstein, E., \& A. J. Bцoom. 2005. Mineral nutrition of plants: Principles and perspective. Editorial Sinauer, Los Angeles. xiv $+380 \mathrm{pp}$.

Evangelou, M.W.H., M. Ebel \& A. Schaeffer. 2007. Review: Chelate assisted phytoextraction of heavy metals from soil. Effect, mechanism, toxicity, and fate of chelating agents. Chemosphere 68(6): 989-1003.

Flemming, C.A. \& T. Trevors. 1989. Copper toxicity and chemistry in the environment: A review. Water, Air and Soil Pollution 44(1-2): 143-158.

Fogarty, R.V., P. Dostalek, M. Patzak, J. Votruba, E. Tel-Or \& J.M. ToBin. 1999. Metal removal by immobilised and non-immobilised Azolla filiculoides. Biotechnology Techniques 13(8): 533-538.

Frankfart, C., P. Eullaffroy \& G. Vernet. 2002. Photosynthetic response of Lemna minor exposed to xenobiots, copper and their combinations. Ecotoxicology and Environmental Safety 53(3): 439-445.

Ghestem, J.P., \& A. Bermond. 1998. EDTA extractability of trace metals in polluted soils: A chemical-physical study. Environmental Technology 19(4): 409-416.

Hall, J.L. 2002. Cellular mechanisms for heavy metal detoxification and tolerance. Journal of Experimental Botany 53(1): 1-11.

Hernández-Allica, J., C. Garbisu, O. Barrutia \& J.M. Becerril. 2007. EDTA-induced heavy metal accumulation and phytotoxicity in cardoon plants. Environmental and Experimental Botany 60(1): 26-32.

Hong, P.K.A., C. Li, S.K. BanerJi \& T. Regmi. 1999. Extraction, recovery, and biostability of EDTA for remediation of heavy metal-contaminated soil. Journal of Soil Contamination 8(1): 81-103.

Hou, W., X. Chen, G. Song, Q. Wang \& C. Chi Chang. 2007. Effects of copper and cadmium on heavy metal polluted waterbody restoration by duckweed (Lemna minor). Plant Physiology and Biochemistry 45(1): 62-69.

Huang, J.W., J. Chen, W.R. Berti \& S. D. Cunningham. 1997. Phytoremediation of lead-contaminated soils: Role of synthetic chelates in lead phytoextraction. Environmental Science and Technology 31(3): 800-805.

January, M.C., T.J. Cutright, H.V. Keulen \& R. Wei. 2008. Hydroponic phytoremediation of $\mathrm{Cd}, \mathrm{Cr}, \mathrm{Ni}, \mathrm{As}$, and $\mathrm{Fe}$ : Can Helianthus annuus hyperaccumulate multiple heavy metals? Chemosphere 70(3): 531-537. 
Jiang, X.J., Y.M. Luo, Q.G. Zhao, A.J.M. Baker, P. Christie \& M.H. Wong. 2003. Soil Cd availability to Indian mustard and environmental risk following EDTA addition to Cdcontaminated soil. Chemosphere 50(6): 813-818.

KARI, F.G. \& W. Giger. 1996. Speciation and fate of ethylenediaminetetraacetate (EDTA) in municipal wastewater treatment. Water Research 30(1): 122-134.

Kayser, A., K. Wenger, A. Keller, W. Attinger, H.R. Felix, S.K. Gupta \& R. Schulin. 2000. Enhancement of phytoextraction of $\mathrm{Zn}, \mathrm{Cd}$, and $\mathrm{Cu}$ from calcareous soil: The use of NTA and sulfur amendments. Environmental Science and Technology 34(9): 1778-1783.

Khosravi, M., M. Taghi Ganji \& R. Rakhshaee. 2005. Toxic effects of $\mathrm{Pb}, \mathrm{Cd}, \mathrm{Ni}$ and $\mathrm{Zn}$ on Azolla filiculoides in the International Anzali Wetland. International Journal of Environmental Science Technology 2(1): 35-40.

Krupa, Z. 1988. Cadmium-induced changes in the composition and structure of the light-harvesting complex II in radish cotyledons. Phisiology Plantarum 73(4): 518-524.

Küpper, H., I. Šetlík, M. SPiller, F. C. Küpper \& O. PrÁŠIL. 2002. Heavy metal-induced inhibition of photosynthesis: Targets of in vivo heavy metal chlorophyll formation. Journal of Phycology 38(3): 429-441.

Kulli, B., M. Balmer, R. Krebs, B. Lothenbach, G. Geiger \& R. Schulin. 1999. The influence of nitrilotriacetate on heavy metal uptake of lettuce and ryegrass. Journal Environmental Quality 28(6): 1699-1705.

Lasat, M.M. 2002. Phytoextraction of toxic metals: A review of biological mechanisms. Journal of Environmental Quality 31(1): 109-120.

Li, Y., J. Liu, Y. Liu \& X. LI. 2009. Effects of EDTA on mechanism of lead accumulation in Typha orientalis Pres. Bulletin of Environmental Contamination and Toxicology 83(4): 553-557.

Lombi, E., F.J. Zhao, S.J. Dunham \& S.P. McGrath. 2001. Phytoremediation of heavy metal-contaminated soils. Journal of Environmental Quality 30(6): 1919-1926.

LoNG, G.L. \& J.D. WINEFORDNER. 1983. Limit of detection: A closer look at the IUPAC definition. Analytical Chemistry 55(7): 712A- 724A.

Lumpkin, T. \& D. Plucknett. 1980. Azolla: Botany, physiology, and use as a green manure. Economic Botany 34(2): 111-153.

Luo, C., Z. SHEn \& X. Li. 2005. Enhanced phytoextraction of Cu, $\mathrm{Pb}, \mathrm{Zn}$ and $\mathrm{Cd}$ with EDTA and EDDS. Chemosphere 59(1): 1-11.

Luo, C., Z. Shen, L. Lou \& X. Li. 2006. EDDS and EDTAenhanced phytoextraction of metals from artificially contaminated soils and residual effects of chelant compounds. Environmental Pollution 144: 862-871.

MaKsymiec, W. 1998. Effect of copper on cellular processes in higher plants. Photosynthetica 34(3): 321-342.

Mal, T.K., P. Adorjan \& A.L. Corbett. 2002. Effect of copper on growth of an aquatic macrophyte Elodea canadensis. Environmental Pollution 120(2): 307-311.

Marchner, H. 1995. Mineral nutrition of higher plants. Elsevier Science, London. 889 pp.

MashKani, S.G., \& P.T.M. Ghazvini. 2009. Biotechnological potential of Azolla filiculoides for biosorption of Cs and Sr: Application of micro-PIXE for measurement of biosorption. Bioresource Technology 100(6): 19151921.

Maxwell, K. \& G.N. Johnson. 2000. Chlorophyll fluorescence-a practical guide. Journal of Experimental Botany 51(345): 659-668.

McGrath, S.P. \& F.-J. Zhao. 2003. Phytoextraction of metals and metalloids from contaminated soils. Current Opinion in Biotechnology 14(3): 277-282.

McGrath, S.P., F.-J. Zhao \& E. Lombi. 2002. Phytoremediation of metals, metalloids and radionuclides. Advances in Agronomy 75(1): 1-56.

Meers, E., A. Ruttens, M.J. Hopgood, D. SAmson \& F.M.G. Tack. 2005. Comparison of EDTA and EDDS as potential soil amendments for enhanced phytoextraction of heavy metals. Chemosphere 58: 1011-1022.

Mishra, S., S. Srivastava, R.D. Tripathi, S. Dwivedi \& M.K. SHUKLA. 2008. Response of antioxidant enzymes in coontail (Ceratophyllum demersum L.) plants under cadmium stress. Environmental Toxicology 23(3): 294301.

Mohan, B.S. \& B.B. Hosetti. 1997. Potential phytotoxicity of lead and cadmium to Lemna minor grown in sewage stabilization ponds. Environmental Pollution 98(2): 233238.

Murata, N., S. Takahashi, Y. Nishiyama \& S.I. AllakhVerdiev. 2007. Photoinhibition of photosystem II under environmental stress. Biochimica et Biophysica Acta 1767(6): 414-421.

NöRTEMAnN, B. 1999. Biodegration of EDTA. Applied Microbiology and Biotechnology 51(6): 751-759.

Nriagu, J.O. \& J.M. Pacyna. 1988. Quantitative assessment of worldwide contamination of air, water and soils by trace metals. Nature 333(6169): 134-139.

RAI, P.K. 2008. Phytoremediation of $\mathrm{Hg}$ and $\mathrm{Cd}$ from industrial effluents using an aquatic free floating macrophyte Azolla pinnata. International Journal of Phytoremediation 10: 430-439.

Raskin, I., N. Kumar, V. Dushenkov \& D.E. Salt. 1994. Bioconcentration of heavy metals by plants. Current Opinion in Biotechnology 5(3): 285-290.

Raskin, I., R.D. Sмith \& D.E. SALt. 1997. Phytoremediation of metals: using plants to remove pollutants from the environment. Current Opinion in Biotechnology 8(2): 221-226.

Rensing, C., Y. Sun, B. Mitra \& B.P. Rosen. 1998. Pb(II)translocating P-type ATPases. Journal of Biological Chemistry 273(49): 32614-32617.

Römkens, P., L. Boumman, J. Japenga \& C. Draaisma. 2002. Potentials and drawbacks of chelate-enhanced phytoremediation of soils. Environment Pollution 116: 109-121.

Saifullah, E. Meers, M. Qadir, P. de Caritat, F.M.G. Tack, G. Du LaInG \& M.H. Zia. 2009. Review: EDTA-assisted Pb phytoextraction. Chemosphere 74: 1279-1291.

SALKIND, N.J. 1999. Capítulo 9: Métodos de Investigación no experimentales. En: N.J. SALKInd (ed.), Métodos de investigación, Tercera Edición, pp.203-210. Prentice Hall, Mexico.

SÁnchez-Viveros, G., D. GonzÁlez-Mendoza, A. Alarcón \& R. Ferrera-Cerrato. 2010. Copper effects on 
photosynthetic activity and membrane leakage of Azolla filiculoides and $A$. caroliniana. International Journal of Agriculture and Biology 12(3): 365-368.

SAndmanN, G. \& P. Böger. 1980. Copper-mediated lipid peroxidation processes in photosynthetic membranes. Plant Physiology 66(5): 797-800.

SANITÀ DI ToppI, L. \& R. GABBRIELli. 1999. Response to cadmium in higher plants. Environmental and Experimental Botany 41(2): 105-130.

SARKar, A. \& S. Jana. 1986. Heavy metal pollutant tolerance of Azolla pinnata. Water, Air and Soil Pollution 27(1): 1518.

Sela, M., J. Garty \& E. Tel-Or. 1989. The accumulation and the effect of heavy metals on the water fern Azolla filiculoides. New Phytologist 112(1): 7-12.

Sela, M., E. Tel-Or, E. Fritz \& A. Huttermann. 1988. Localization and toxic effects of cadmium, copper, and uranium in Azolla. Plant Physiology 88(1): 30-36.

Shen, Z.-G., X.-D. Li, C.-C. WAng, H.-M. Chen \& H. Chua. 2002. Lead phytoextraction from contaminated soil with highbiomass plant species. Journal of Environmental Quality 31(6): 1893-1900.

Siedlecka, A., \& T. BASZyNSKy. 1993. Inhibition of electron flow around photosystem I in chloroplasts of cadmium-treated maize plants is due to cadmium-induced iron deficiency. Physiologia Plantarum 87(2): 199-202.

Siedlecka, A. \& Z. KRUPA. 1996. Interaction between cadmium and iron and its effects on photosynthetic capacity of primary leaves of Phaseolus vulgaris. Plant Physiology and Biochemistry 34(6): 833-841.

Singh, K.P., D. Mohan, S. Sinha \& R. Dalwani. 2004. Impact assessment of treated/untreated wastewater toxicants discharged by sewage treatment plants on health, agricultural, and environmental quality in the wastewater disposal area. Chemosphere 55(2): 227-255.

Sivaci, A., E. Elmas, F. Gümüș \& E. Sivaci. 2008. Removal of cadmium by Myriophyllum heterophyllum Michx. and Potamogeton crispus L. and its effect on pigments and total phenolic compounds. Archives of Environmental Contamination and Toxicology 54(4): 612-618.

Sood, A., P. Uniyal, R. Prasanna \& A. Ahluwalia. 2011. Phytoremediation potential of aquatic macrophyte Azolla. AMBIO 1-16.

Stepniewska, Z., R.P. Bennicelli, T.I. Balakhnina, K. Szajnocha, A. Banach \& A. WolinsKa. 2005. Potential of Azolla caroliniana for the removal of $\mathrm{Pb}$ and $\mathrm{Cd}$ from wastewaters. International Agrophysics 19(3): 251-255.

Sun, Y., Q. Zhou, L. WANG \& W. LiU. 2009. The Influence of different growth stages and dosage of EDTA on $\mathrm{Cd}$ uptake and accumulation in Cd-hyperaccumulator (Solanum nigrum L.). Bulletin of Environmental Contamination and Toxicology 82(3): 348-353.

Thayalakumaran, T., B.H. Robinson, I. Vogeler, D. R. Scotter, B.E. Clothier \& H.J. Percival. 2003. Plant uptake and leaching of copper during EDTA-enhanced phytoremediation of repacked and undisturbed soil. Plant and Soil 254: 415-423.

TyystuärVI, E. 2008. Photoinhibition of Photosystem II and photodamage of the oxygen evolving manganese cluster. Coordination Chemistry Reviews 252(3-4): 361-376.

Valderrama, A., J. Tapia, P. Peñailillo \& D.E. Carvajal. 2013. Water phytoremediation of cadmium and copper using Azolla filiculoides Lam. in a hydroponic system. Water and Environment Journal 27(3): 293-300.

Vavilin, D.V., V.A. Polynov, D.N. Matorin \& P.S. Venediktov. 1995. Sublethal concentrations of copper stimulate photosystem II photoinhibition in Chlorella pyrenoidosa. Journal of Plant Physiology 146(5-6): 609-614.

Watanabe, I., P. A. Roger, J. K. Ladha \& A. Van Hove. 1992. Biofertilizer germplasm collection at IRRI. International Rice Research Institute, Philippines. v 66 pp.

Weigel, H.J. 1985. Inhibition of photosynthetic reactions of isolated intact chloroplasts by cadmium. Journal of Plant Physiology 119(2): 179-189.

Wenzel, W.W., R. Unterbrunner, P. Sommer \& P. SAcco. 2003. Chelate-assisted phytoextraction using canola (Brassica napus L.) in outdoors pot and lysimeter experiments. Plant and Soil 249: 83-96.

Weser, U., L.M. Shubotz \& M. Younes. 1979. Part II: Health effects. In: J.O. NRIAGU (ed.), Copper in the environment, pp. 197-240. John Wiley and Sons, Toronto.

Williams, L.E., J.K. Pittman \& J.L. Hall. 2000. Emerging mechanisms for heavy metal transport in plants. Biochimica et Biophysica Acta 1465: 104-126.

Wong, J.W.C., W.W.Y. Wong, Z. Wei \& H. JagadeEsan. 2004. Alkaline biosolids and EDTA for phytoremediation of an acidic loamy soil spiked with cadmium. Science of the Total Environment 324: 235-246.

ZhaO, M. \& J.R. Duncan. 1997. Bath removal of sexivalent chromium by Azolla filiculoides. Biotechnology and Applied Biochemistry 26(3): 179-182.

Zhao, Z., M. Xi, G. JiAnG, X. Liu, Z. Bai \& Y. Huang. 2010. Effects of IDSA, EDDS and EDTA on heavy metals accumulation in hydroponically grown maize (Zea mays L.). Journal of Hazardous Materials 181(1-3): 455-459.

Recibido: 11.11 .15

Aceptado: 10.08.16 